\title{
Rancang Bangun Robot Tank Automatik Pendeteksi Halangan dengan Kendali Fuzzy Logic
}

\author{
Julianto Rebbi Badidi ${ }^{1}$, Ervan Asri², Ratna Aisuwarya ${ }^{3}$ \\ 1,3 Jurusan Sistem Komputer FTI Universitas Andalas, Jln. Kampus Limau Manis Kota Padang 25163 INDONESIA \\ ${ }^{2}$ Jurusan Teknologi Informasi Politeknik Negeri Padang, Jln. Kampus Limau Manis Kota Padang 25163 INDONESIA
}

\section{ARTICLE INFORMATION}

Received: December 26,2017

Revised: February 15, 2018

Available online: March 29. 2018

\section{KEYWORDS}

Raspberry Pi, sensor PIR, Smart Phone

CORRESPONDENCE

E-mail: ratna.aisuwarya@ fti.unand.ac.id

\section{A B S T T R A C T}

Robotics is a field of science that is developing rapidly, One of Robotic field is a wheeled robot whose sample application allows robots to explore automatically. But today, more research on the application of artificial intelligence in robot control is aimed at obtaining sophisticated kinematic control. In this final project, a wheeled robot will be designed with the ability to detect obstacles. As a control object is a robot tank that both wheels use a belt wheel and have a separate DC motor. A fuzzy logic controller functions to regulate the speed and direction of the robot's motion based on the input of the ultrasonic sensor. The design of robots based on the embedded microcontroller is designed using the $\mathrm{C}$ language. From the test results, that fuzzy logic can be embedded in the ATmega328 microcontroller control unit on Arduino Uno, so that a robotic motion can be avoided that can avoid obstacles properly. The closer the obstacle distance results in the sharpening direction of the robot and the more rigorous robot movement.

\section{PENDAHULUAN}

Perkembangan robot pada saat ini semakin canggih dan bervariasi mulai dari robot beroda hingga berkaki. Robot beroda juga mengalami perkembangan dari yang beroda biasa, hingga menyerupai roda tank. Kelebihan dari bentuk roda tank ini adalah dapat melewati medan mendaki maupun menurun, ataupun medan yang tidak rata dan bergelombang yang tidak dapat dengan mudah dilalui oleh robot beroda konvensional. Metode yang dapat digunakan untuk mendukung pembuatan kecerdasan buatan pada robot sehingga dapat berpindah tempat tanpa campur tangan manusia satu diantaranya adalah fuzzy logic. Fuzzy logic mempunyai sifat yang fleksibel, artinya mampu beradaptasi dengan perubahan-perubahan, dan ketidakpastian serta memiliki kelebihan dalam proses penalaran secara bahasa sehingga mudah dimengerti. Input yang digunakan adalah kemampuan menghindari halangan melalui sensor ultrasonik. Kecepatan dari dua motor DC akan dikendalikan berdasarkan perubahan jarak terhadap suatu halangan dan akan mengambil keputusan arah mana yang akan ditempuh melalui kendali fuzzy logic.

\section{LANDASAN TEORI}

\subsection{Robot}

Menurut Robotics Institute of America (RIA) robot adalah manipulator multifungsi yang dapat diprogram kembali dan dibuat untuk tujuan pemindahan material, komponen dan https://doi.org/10.25077/jitce.2.01.7-18.2018 peralatan atau merupakan alat tertentu yang dikhususkan untuk dapat bergerak sesuai program yang diberikan agar dapat melakukan berbagai tugas tertentu.[1]

\subsubsection{Bentuk Robot}

1. Stationary dan Mobile

Beberapa robot dirancang untuk tetap berada pada posisinya dan menggerakkan beberapa obyek yang berada di depannya. Robot stasionary umumnya digunakan di pabrik.

2. Teleoperated dan Autonomous

Robot Teleoperated bergerak berdasarkan perintah dari manusia yang dioperasikan melalui remote control. Biasanya robot ini menggunakan kamera sebagai mata untuk operator. Autonomous robot (robot otonom) bergerak tanpa interferensi manusia. Robot otonom mempunyai tenaga sendiri, brain, locomotion (daya penggerak), sensor, dan alat lainnya. Aksi yang dilakukan oleh robot otonom dikendalikan melalui software yang tertanam di mikrokontroler (brain) dari robot tersebut.[2]

2.1 Robot Tank

Istilah Robot Tank mulai dikenal pada tahun 1930 ketika Uni Soviet mengeoperasikan teletank, tank untuk perang pada masa itu. Sistem kontrol robot tersebut dimodifikasi, lalu pneumatic, relay listrik, serta sinyal radio digunakan untuk mengontrol robot tank tersebut dari jarak 500-1500 meter. Jarak jangkauan ini tergantung cuaca dan kondisi lainnya. Robot tank yang dibuat harus kokoh dan stabil. Robot yang berjalan terlalu miring dapat membuat robot jatuh atau terguling. [3]

\subsection{Mikrokontroler}

Attribution-NonCommercial 4.0 International. Some rights reserved 
Mikrokontroler adalah sebuah sistem komputer yang dibangun pada sebuah keeping (chip) tunggal yang disusun dari beberapa komponen yaitu CPU (Central Processing Unit), ROM (Read Only Memori), RAM (Random Access Memory), dan I/O (Input/Output). Keempat komponen ini secara bersama-sama membentuk sistem komputer dasar. Beberapa mikrokontroler memiliki tambahan komponen lain, seperti ADC (Analog Digital Converter), Timer/Counter dan lain-lain.[4]

\subsubsection{Mikrokontroler ATmega328}

ATMega328 adalah mikrokontroler keluaran dari atmel yang mempunyai arsitektur RISC (Reduce Instruction Set Computer) yang dimana setiap proses eksekusi data lebih cepat dari pada arsitektur CISC (Completed Instruction Set Computer). Pada mikrokontroler ini terdapat beberapa fitur :

130 macam instruksi yang hampir semuanya dieksekusi dalam satu siklus clock.

$32 \times 8$-bit register serba guna.

Kecepatan mencapai 16 MIPS dengan clock 16 MHz.

$32 \mathrm{~KB}$ Flash memory dan pada Arduino memiliki bootloader yang menggunakan $2 \mathrm{~KB}$ dari flash memori sebagai bootloader.

Memiliki EEPROM (Electrically Erasable Programmable Read Only Memory)

sebesar $1 \mathrm{~KB}$ sebagai tempat penyimpanan data semi permanen karena EEPROM tetap dapat menyimpan data meskipun catu daya dimatikan.

Memiliki pin I/O digital sebanyak 14 pin, 6 diantaranya

PWM (Pulse Width Modulation) output.

Mikrokontroler ATmega328 memiliki arsitektur Harvard, yaitu memisahkan memori untuk kode program dan memori untuk data sehingga dapat memaksimalkan kerja dan paralelisasi. Instruksi-instruksi dalam memori program dieksekusi dalam satu alur tunggal, dimana pada saat satu instruksi dikerjakan instruksi berikutnya sudah diambil dari memori program. Konsep inilah yang memungkinkan instruksi-instruksi dapat dieksekusi dalam setiap satu siklus clock. Ketiga register pointer 16-bit ini disebut dengan register $\mathrm{X}$ ( gabungan R26 dan R27), register $\mathrm{Y}$ ( gabungan R28 dan R29 ), dan register Z ( gabungan R30 dan R31 ).[5]

\subsubsection{Arduino}

Arduino adalah prototype elektronik platform open source yang fleksibel, dan mudah digunakan. Arduino dapat menerima masukan dari berbagai sensor untuk mengontrol lampu, motor, ataupun aktuator lainnya. Proyek Arduino dapat berdiri sendiri atau mereka dapat berkomunikasi dengan perangkat lunak yang berjalan pada komputer.

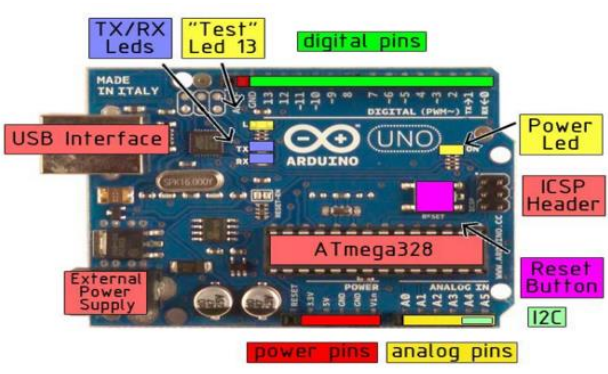

Gambar 2.1 Board Arduino Uno ATmega 328[5]

Pada arduino uno terdapat 14 pin output/input yang mana 6 pin dpat digunakan sebagai output PWM, 6 analog input, crystal osilator $16 \mathrm{MHZ}$, tombol reset dan mikrokontroler ATmega328.[5]

\subsubsection{Pemrograman Arduino}

IDE Arduino adalah software yang ditulis dengan menggunakan Java. IDE Arduino terdiri dari:

Editor program, sebuah window yang memungkinkan pengguna menulis dan mengedit program dalam bahasa Processing.

Compiler, sebuah modul yang mengubah kode program (bahasa Processing) menjadi kode biner. Bagaimanapun sebuah mikrokontroler tidak akan bisa memahami bahasa Processing. Yang bisa dipahami oleh mikrokontroler adalah kode biner. Itulah sebabnya compiler diperlukan dalam hal ini.

Uploader, sebuah modul yang memuat kode biner dari komputer ke dalam memori di dalam papan Arduino.[5]

\subsection{Sensor Ultrasonik}

Sensor ultrasonik adalah sensor jarak yang bekerja dengan mengirimkan gelombang ultrasonik (diatas ambang batas pendengaran manusia) dan menyediakan pulsa keluaran yang berkaitan dengan waktu yang dibutuhkan saat gelombang pantulan diterima kembali oleh sensor. Dengan mengukur jeda waktu pulsa kirim terhadap pulsa yang diterima, maka jarak yang diukur dapat dikalkulasikan. Sensor Ultrasonik memiliki presisi pengukuran tanpa kontak dengan titik ukur dari $2 \mathrm{~cm}$ hingga 450 $\mathrm{cm}$.[8]

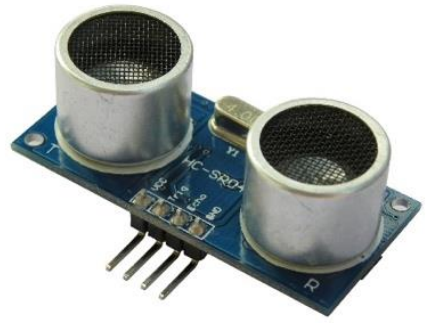

Gambar 2.2 Sensor Jarak Ultrasonik HC-SR04[9]

Beberapa fasilitas yang dimiliki oleh sensor ultrasonik HC-SR04 :

a. Power Supply +- 5V DC

b. Arus diam $<2 \mathrm{~mA}$

c. Arus bekerja $15 \mathrm{~mA}$

d. Resolusi 0,3 cm

e. Ultrasonik frekuensi $40 \mathrm{kHz}$

f. Sudut ukur $30^{\circ}$

g. Ukurannya $20 \mathrm{~mm} \mathrm{H} \mathrm{x} 45 \mathrm{~mm} \mathrm{~W}$ x $15 \mathrm{~mm} \mathrm{D}$

Sensor ultrasonik HC-SR04 mempunyai 4 pin kepala (header) untuk jalur power supply, ground, trigger pin, dan echo pin.

Sensor ultrasonik HC-SR04 mendeteksi objek dengan mengirimkan pulsa-pulsa pendek ultrasonik dan kemudian menunggu gelombang pantulan (echo). Sensor ini membutuhkan pulsa penyulut (trigger pulse) dengan mengantarmukakan piranti pengendali (mikrokontroller) sehingga pengiriman gelombang ultrasonik $40 \mathrm{kHz}$ pendek oleh sensor akan menunggu instruksi dari pengendali. Gelombang ultrasonik merambat di udara dengan kecepatan 1.130 kaki perdetik (340 m/s), yang akan membentuk objek terukur dan memantulkannya kembali menuju 
sensor. Sensor ultrasonik mengeluarkan pulsa keluaran kepada pengendali yang akan menentukan saat pantulan terdeteksi. Lebar pulsa pada durasi pengiriman hingga pantulan terdeteksi berhubungan dengan jarak yang terukur.[8]

\section{$2.4 \quad$ Motor DC}

Motor adalah suatu mesin yang berfungsi mengubah tenaga listrik menjadi tenaga mekanik. Pada motor DC (Direct Current) tenaga mekanik tersebut berupa putaran rotor secara kontinu. Pada interface motor DC memerlukan supply arus yang cukup besar, untuk itu diperlukan suatu rangkaian interface antara mikrokontroller port dengan motor untuk mendapatkan supply arus yang cukup. Interface ini dapat diimplementasikan dengan berbagai macam komponen, antara lain: relay, bipolar transistor, power mosfet, dan motor driver integrated circuit.

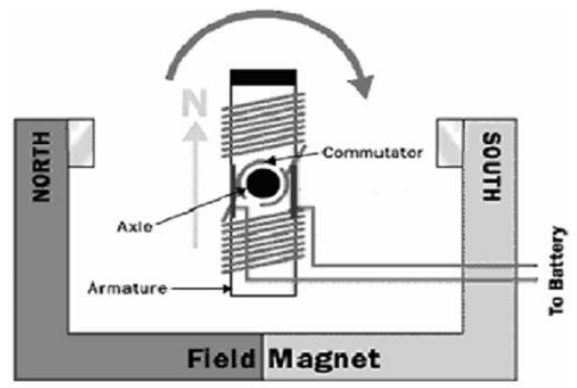

Gambar 2.3 Detail Mekanik Motor DC[10]

Prinsip kerja dari motor DC berdasarkan pada penghantar yang membawa arus kedalam kumparan sehingga kumparan akan menimbulkan medan magnet. Medan magnet ini dibuat sedemikian rupa sehingga keadaannya selalu tolak menolak antara medan magnet yang ditimbulkan stator dan medan magnet yang ditimbulkan rotor sehingga didapat gaya dorong diantara keduanya maka timbulah putaran.[10]

\subsubsection{Driver Motor IC L298}

IC L298 adalah jenis IC driver motor yang dapat mengendalikan arah putaran dan kecepatan motor DC ataupun motor stepper. Mampu mengeluarkan output tegangan untuk motor DC dan motor stepper sebesar 50 volt. IC L298 terdiri dari transistor-transistor logika (TTL) dengan gerbang NAND yang memudahkan dalam menentukkan arah putaran suatu motor DC dan motor stepper.[11]

\subsubsection{Arduino Motor Shield (L298P)}

L298 driver motor shield menggunakan driver Hbridge Chip L298P, yang mampu mendorong motor DC, dua fase atau empat fase stepper motor dengan maksimal Arus 2A. Rangkaian motor shield dapat ditumpuk dan membuatnya mountable ke Arduino Duemilanove, Uno, atau Mega. Motor shield dapat diaktifkan langsung dari Arduino atau dari sumber daya eksternal. Shield dapat beralih di antara PWM speed control dan PLL (Phase Lock Loop) advance speed control Spesifikasi

- 2 arah 7-12V motor drive

- Up to $2 \mathrm{~A}$ current masing arah

- Pin 5,6,7,8 digunakan untuk drive 2 motor DC

- Mendukung PWM speed control

- Mendukung PLL advance speed control[12]

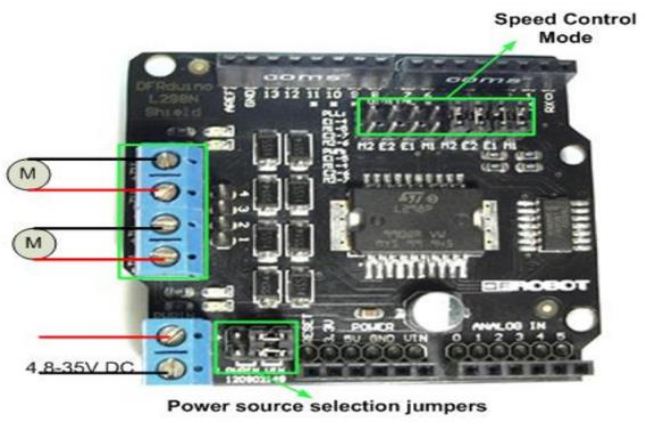

Gambar 2.4 Arduino Motor Shield[11]

]

2.5 Pulse Width Modulation (PWM)

Pulse Width Modulation (PWM) berfungsi untuk menghasilkan pulsa-pulsa yang dapat diatur lebarnya berdasarkan penggunaan timer/counter yang sudah ada.

Daya disuplai ke motor dalam bentuk sinyal gelombang persegi yang amplitudanya konstan tetapi lebar pulsanya atau duty cycle berubah-ubah. Duty Cycle adalah persentasi waktu pulsa high terhadap perioda pulsa. Untuk kecepatan yang paling rendah (lambat), daya disuplai pada seperempat waktu siklus (duty cycle $25 \%$ ). Untuk duty cycle $50 \%$ (daya pada separuh waktu), motor akan berputar pada kecepatan setengah dan seterusnya. Pada praktisnya, faktor nonlinier menyebabkan motor berputar lebih lambat dari proporsi yang seharusnya.[12]

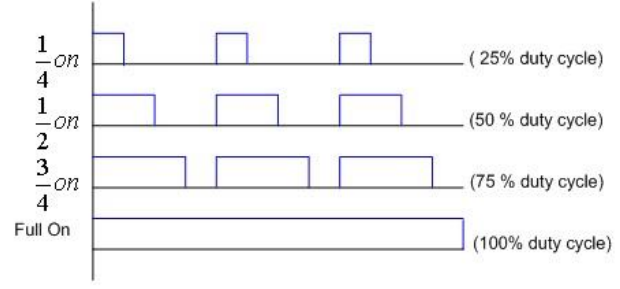

Gambar 2.5 Bentuk Gelombang PWM[12]

2.6 Metode Fuzzy Logic Controller

Logika fuzzy adalah metodologi sistem control pemecahan masalah, yang cocok untuk diimplementasikan pada sistem, mulai dari sistem yang sederhana, sistem kecil, embedded system, jaringan PC, multi-channel atau workstation berbasis akuisisi data dan sistem kontrol. Metodologi ini dapat diterapkan pada perangkat keras, perangkat lunak atau kombinasi keduanya. Dalam logika klasik dinyatakan bahwa segala sesuatu bersifat biner yang artinya hanya mempunyai dua kemungkinan "Ya atau Tidak", "Benar atau Salah", "Baik atau Buruk", dan lain sebagainya. Oleh karena itu, semua ini dapat mempunyai nilai keanggotaan 0 atau 1. Akan tetapi, dalam logika fuzzy memungkinkan nilai keanggotaan berada diantara 0 dan 1 .

Beberapa alasan yang dapat diutarakan mengapa menggunakan logika fuzzy adalah mudah dimengerti, memiliki toleransi terhadap data-data yang tidak tepat, mampu memodelkan fungsi-fungsi nonlinier yang sangat kompleks, dapat membangun dan mengaplikasikan pengalaman-pengalaman para pakar secara langsung tanpa harus melalui proses pelatihan, 
dapat bekerja sama dengan teknik-teknik kendali secara konvensional dan didasarkan pada bahasa alami.

\subsubsection{Model-model Logika Fuzzy}

+ Model Mamdani

Sistem samar model Mamdani disebut juga dengan metode max untuk mendapatkan keluaran pada metode ini, diperlukan 4 tahapan yaitu :

Pembentukan himpunan samar

Penggunaan Fungsi Implikasi min.

Penarikan Kesimpulan / Komposisi Aturan (metode $\max$ ).

Defuzzifikasi (Centroid, Bisektor, Mean of Maximum, Largest of Maximum atau Smallest of Maximum).

+ Model Sugeno (TSK)

Sistem samar model Sugeno juga dikenal dengan nama model TSK. Model Sugeno merupakan usaha untuk mengembangkan pendekatan sistematis untuk membangun aturan samar dari himpunan data masukan dan keluaran. Aturan samar pada model sugeno biasanya diwujudkan dalam susunan :

JIKA $x$ adalah A dan y adalah B maka $z=f(x, y)$

yang mana $A$ dan $B$ adalah himpunan samar pada anteseden, dan $\mathrm{z}=\mathrm{f}(\mathrm{x}, \mathrm{y})$ merupakan fungsi crisp pada konsekuen $\mathrm{f}(\mathrm{x}, \mathrm{y})$ biasanya merupakan polinomial pada variabel masukan $\mathrm{x}$ dan $\mathrm{y}$, tetapi dapat berupa fungsi. Jika $\mathrm{f}(\mathrm{x}, \mathrm{y})$ merupakan polinomial orde 1 maka hasil dari sistem inferensi samar disebut model samar sugeno orde 1. Ketika f merupakan konstanta maka sistem inferensi samarnya disebut model samar sugeno orde 0 . + Model Tsukamoto

Dalam sistem samar model tsukamoto, konsekuen pada setiap aturan samar JIKA-MAKA diwakili oleh himpunan samar dengan fungsi keanggotaan monoton. Nilai hasil pada konsekuen setiap aturan samar berupa nilai crisp yang diperoleh berdasarkan fire strength pada antesedennya. Keluaran sistem dihasilkan dari konsep rata-rata terbobot dari keluaran setiap aturan samar.[13]

\section{METODOLOGI PENELITIAN}

3.1

Jenis Penelitian

Penelitian adalah suatu proses yang sistematis dalam mengumpulkan dan menganalisa suatu data. Penelitian ini menggunakan experimental research atau penelitian eksperimen berkenaan dengan kenyataan-kenyataan praktis, yaitu eksperimen dan pengembangan pengetahuan yang dihasilkan oleh penelitian dasar dalam kehidupan nyata.[14]

Selain itu juga perlu adanya pendekatan ilmiah untuk memunculkan pengetahuan baru. Penelitian ini menggunakan pendekatan engineering approach menghasilkan suatu bentuk produk. Penelitian ini menggunakan pendekatan engineering approach, karena dari penelitian ini akan menghasilkan suatu produk dalam bentuk prototype.[15]

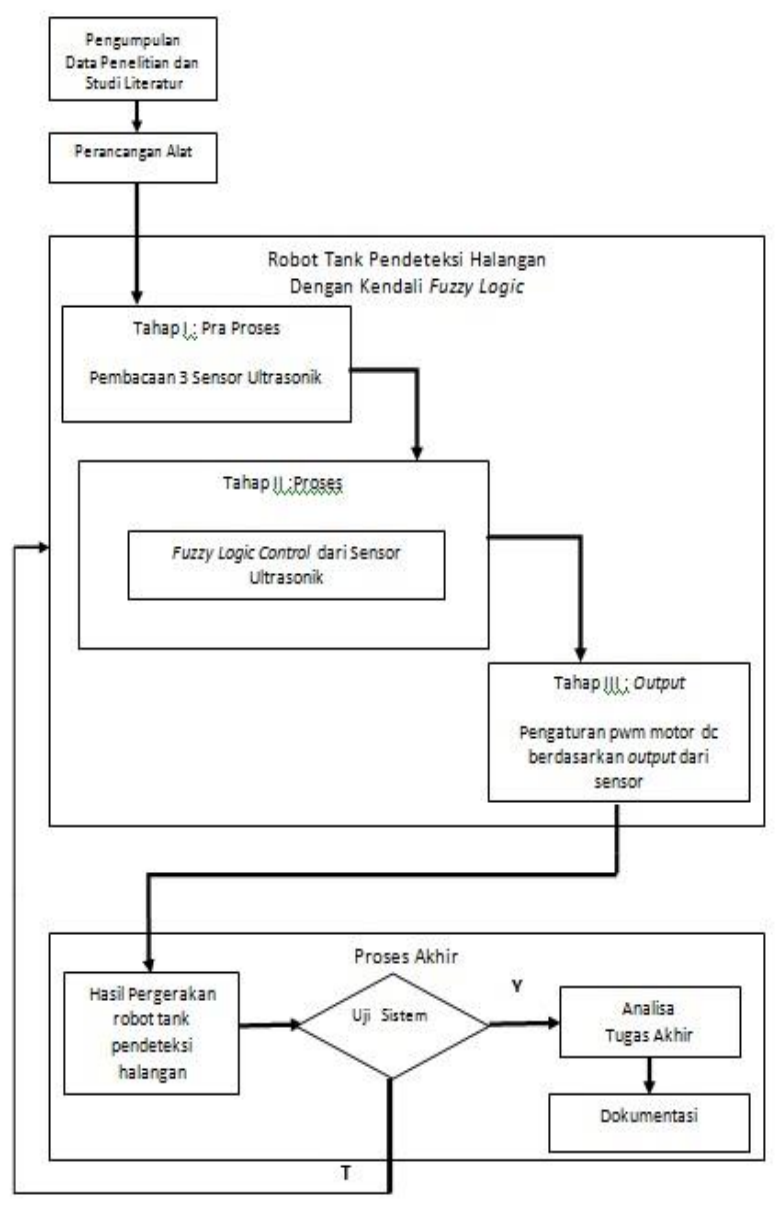

Gambar 3.1 Desain Penelitian

Robot Tank dibuat dari berbagai macam komponen yang saling melengkapi. Motor DC digunakan sebagai mesin penggerak robot, dimana kecepatan dari masingmasing motor tergantung PWM (Pulse Width Modulation) yang dihasilkan dari driver motor. Driver motor yang telah mounted dengan Arduino Uno mendapat input dari sensor ultrasonik. Sensor Ultrasonik memberi input berupa jarak penghalang dari depan, kiri, dan kanan.

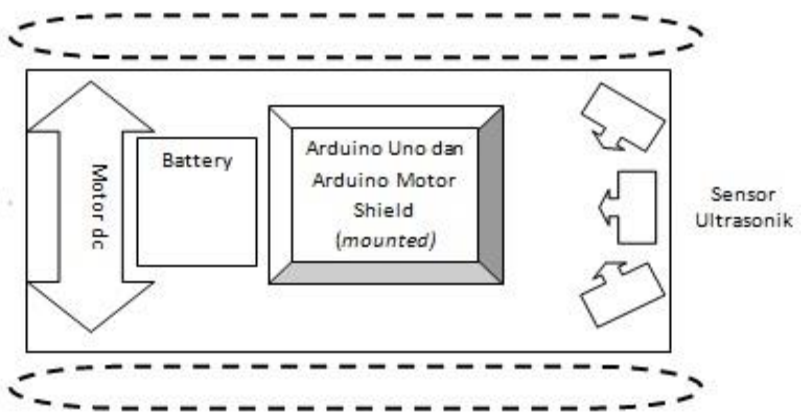

Gambar 3.2 Susunan Komponen Robot Tank 


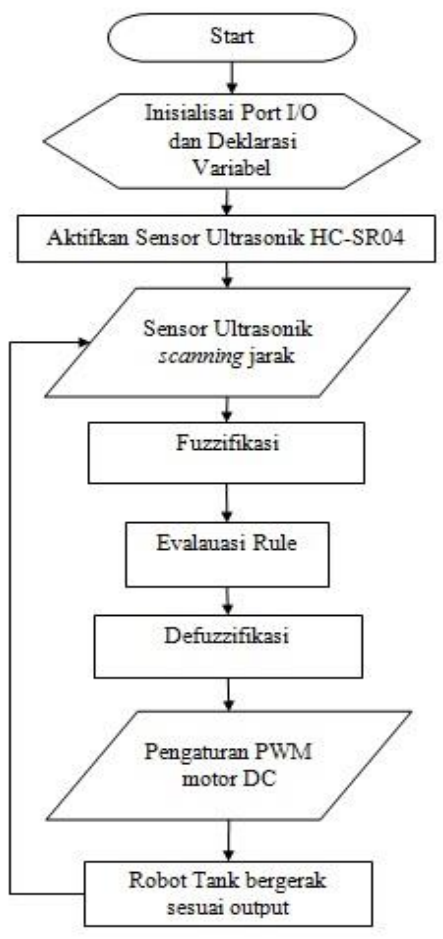

Gambar 3.3 Flowchart Robot Tank Pendeteksi Halangan

Seperti terlihat pada flowchat, robot tank akan scanning jarak di sekitar robot yang selanjutnya akan di proses dengan kendali fuzzy logic. Dalam proses fuzzifikasi ini terdapat 3 input yaitu sensor ultrasonik sisi kiri, depan, dan kanan. Untuk setiap input diberi label Very Near (VN), Near (N), Medium (M), Far (F) dan Very Far (VF)

Berikut table Rule Evaluation :

Tabel 3.1 Rule Evaluation

\begin{tabular}{|c|c|c|c|c|c|}
\hline No. & Left & Center & Right & MTRKi & MTRKa \\
\hline 1 & VN & VN & VN & B & B \\
\hline 2 & VN & VN & $\mathrm{N}$ & VF & VS \\
\hline 3 & $\mathrm{VN}$ & VN & M & VF & $\mathrm{S}$ \\
\hline 4 & $\mathrm{VN}$ & VN & F & $\mathrm{F}$ & VS \\
\hline 5 & VN & VN & VF & $\mathrm{F}$ & $S$ \\
\hline 6 & $\mathrm{VN}$ & $\mathrm{N}$ & $\mathrm{VN}$ & B & B \\
\hline 7 & $\mathrm{VN}$ & $\mathrm{N}$ & $\mathrm{N}$ & VF & S \\
\hline 8 & $\mathrm{VN}$ & $\mathrm{N}$ & $M$ & $\mathrm{~F}$ & VS \\
\hline 9 & $\mathrm{VN}$ & $\mathrm{N}$ & F & F & $S$ \\
\hline 10 & $\mathrm{VN}$ & $\mathrm{N}$ & VF & $\mathrm{M}$ & VS \\
\hline 11 & $\mathrm{VN}$ & $\mathrm{M}$ & VN & VS & VS \\
\hline 12 & $\mathrm{VN}$ & $\mathrm{M}$ & $\mathrm{N}$ & $\mathrm{S}$ & VS \\
\hline 13 & $\mathrm{VN}$ & $\mathrm{M}$ & $\mathrm{M}$ & $\mathrm{M}$ & VS \\
\hline 14 & $\mathrm{VN}$ & $\mathrm{M}$ & $\mathrm{F}$ & $\mathrm{M}$ & $S$ \\
\hline 15 & $\mathrm{VN}$ & M & VF & M & $\mathrm{S}$ \\
\hline 16 & $\mathrm{VN}$ & $\mathrm{F}$ & VN & $S$ & $S$ \\
\hline 17 & $\mathrm{VN}$ & $\mathrm{F}$ & $\mathrm{N}$ & $S$ & VS \\
\hline 18 & $\mathrm{VN}$ & $\mathrm{F}$ & M & M & S \\
\hline 19 & $\mathrm{VN}$ & $\mathrm{F}$ & $\mathrm{F}$ & $\mathrm{M}$ & $\mathrm{S}$ \\
\hline 20 & $\mathrm{VN}$ & $\mathrm{F}$ & $\mathrm{VF}$ & $\mathrm{F}$ & $S$ \\
\hline 21 & $\mathrm{VN}$ & $\mathrm{VF}$ & VN & $\mathrm{S}$ & $\mathrm{S}$ \\
\hline 22 & $\mathrm{VN}$ & $\mathrm{VF}$ & $\mathrm{N}$ & S & VS \\
\hline
\end{tabular}

\begin{tabular}{|c|c|c|c|c|c|}
\hline 23 & VN & VF & $M$ & $\mathrm{M}$ & $S$ \\
\hline 24 & $\mathrm{VN}$ & VF & $\mathrm{F}$ & $F$ & $\mathrm{~S}$ \\
\hline 25 & VN & VF & VF & $F$ & $\mathrm{M}$ \\
\hline 26 & $\mathrm{~N}$ & $\mathrm{VN}$ & VN & VS & VF \\
\hline 27 & $\mathrm{~N}$ & $\mathrm{VN}$ & $\mathrm{N}$ & VF & VS \\
\hline 28 & $\mathrm{~N}$ & $\mathrm{VN}$ & $\mathrm{M}$ & VF & $\mathrm{S}$ \\
\hline 29 & $\mathrm{~N}$ & VN & $\mathrm{F}$ & $\mathrm{F}$ & VS \\
\hline 30 & $\mathrm{~N}$ & $\mathrm{VN}$ & VF & $\mathrm{F}$ & $S$ \\
\hline 31 & $\mathrm{~N}$ & $\mathrm{~N}$ & VN & $\mathrm{S}$ & VF \\
\hline 32 & $\mathrm{~N}$ & $\mathrm{~N}$ & $\mathrm{~N}$ & VF & $S$ \\
\hline 33 & $\mathrm{~N}$ & $\mathrm{~N}$ & $\mathrm{M}$ & $\mathrm{F}$ & VS \\
\hline 34 & $\mathrm{~N}$ & $\mathrm{~N}$ & F & $\mathrm{F}$ & $S$ \\
\hline 35 & $\mathrm{~N}$ & $\mathrm{~N}$ & $\mathrm{VF}$ & $\mathrm{M}$ & $\mathrm{VS}$ \\
\hline 36 & $\mathrm{~N}$ & $\mathrm{M}$ & $\mathrm{VN}$ & VS & $\mathrm{S}$ \\
\hline 37 & $\mathrm{~N}$ & $\mathrm{M}$ & $\mathrm{N}$ & $S$ & $S$ \\
\hline 38 & $\mathrm{~N}$ & $\mathrm{M}$ & $\mathrm{M}$ & $\mathrm{M}$ & $\mathrm{VS}$ \\
\hline 39 & $\mathrm{~N}$ & $\mathrm{M}$ & $\mathrm{F}$ & $\mathrm{M}$ & $S$ \\
\hline 40 & $\mathrm{~N}$ & $\mathrm{M}$ & VF & $\mathrm{M}$ & $S$ \\
\hline 41 & $\mathrm{~N}$ & $\mathrm{~F}$ & $\mathrm{VN}$ & VS & $\mathrm{S}$ \\
\hline 42 & $\mathrm{~N}$ & $\mathrm{~F}$ & $\mathrm{~N}$ & $\mathrm{~S}$ & $S$ \\
\hline 43 & $\mathrm{~N}$ & $\mathrm{~F}$ & $\mathrm{M}$ & $\mathrm{M}$ & $S$ \\
\hline 44 & $\mathrm{~N}$ & $\mathrm{~F}$ & $\mathrm{~F}$ & $\mathrm{M}$ & $\mathrm{S}$ \\
\hline 45 & $\mathrm{~N}$ & $\mathrm{~F}$ & $\mathrm{VF}$ & $\mathrm{F}$ & $S$ \\
\hline 46 & $\mathrm{~N}$ & VF & $\mathrm{VN}$ & VS & $S$ \\
\hline 47 & $\mathrm{~N}$ & VF & $\mathrm{N}$ & $S$ & $S$ \\
\hline 48 & $\mathrm{~N}$ & VF & $\mathrm{M}$ & $\mathrm{M}$ & $S$ \\
\hline 49 & $\mathrm{~N}$ & VF & $\mathrm{F}$ & $\mathrm{F}$ & $S$ \\
\hline 50 & $\mathrm{~N}$ & VF & VF & $F$ & $\mathrm{M}$ \\
\hline 51 & $\mathrm{M}$ & $\mathrm{VN}$ & $\mathrm{VN}$ & $S$ & VF \\
\hline 52 & $\mathrm{M}$ & $\mathrm{VN}$ & $\mathrm{N}$ & $S$ & $\mathrm{VF}$ \\
\hline 53 & $\mathrm{M}$ & $\mathrm{VN}$ & $\mathrm{M}$ & $S$ & VF \\
\hline No. & Left & Center & Right & MTRKi & MTRKa \\
\hline 54 & $\mathrm{M}$ & $\mathrm{VN}$ & $\mathrm{F}$ & $\mathrm{F}$ & $\mathrm{VS}$ \\
\hline 55 & $\mathrm{M}$ & $\mathrm{VN}$ & $\mathrm{VF}$ & $F$ & $\mathrm{~S}$ \\
\hline 56 & $\mathrm{M}$ & $\mathrm{N}$ & $\mathrm{VN}$ & $\mathrm{VS}$ & $\mathrm{F}$ \\
\hline 57 & $\mathrm{M}$ & $\mathrm{N}$ & $\mathrm{N}$ & VS & $\mathrm{F}$ \\
\hline 58 & $\mathrm{M}$ & $\mathrm{N}$ & $\mathrm{M}$ & VS & $\mathrm{F}$ \\
\hline 59 & $\mathrm{M}$ & $\mathrm{N}$ & $\mathrm{F}$ & $\mathrm{F}$ & $S$ \\
\hline 60 & $\mathrm{M}$ & $\mathrm{N}$ & VF & $\mathrm{M}$ & $\mathrm{VS}$ \\
\hline 61 & $\mathrm{M}$ & $\mathrm{M}$ & $\mathrm{VN}$ & VS & $\mathrm{M}$ \\
\hline 62 & $\mathrm{M}$ & $\mathrm{M}$ & $\mathrm{N}$ & VS & $\mathrm{M}$ \\
\hline 63 & $\mathrm{M}$ & $\mathrm{M}$ & $\mathrm{M}$ & $\mathrm{M}$ & $\mathrm{M}$ \\
\hline 64 & $\mathrm{M}$ & $\mathrm{M}$ & $\mathrm{F}$ & $\mathrm{F}$ & $\mathrm{M}$ \\
\hline 65 & $\mathrm{M}$ & $\mathrm{M}$ & $\mathrm{VF}$ & $\mathrm{F}$ & $\mathrm{M}$ \\
\hline 66 & $\mathrm{M}$ & $\mathrm{F}$ & $\mathrm{VN}$ & $\mathrm{S}$ & $\mathrm{M}$ \\
\hline 67 & $\mathrm{M}$ & $\mathrm{F}$ & $\mathrm{N}$ & $S$ & $\mathrm{M}$ \\
\hline 68 & $\mathrm{M}$ & $\mathrm{F}$ & $\mathrm{M}$ & $\mathrm{M}$ & $\mathrm{M}$ \\
\hline 69 & $\mathrm{M}$ & $\mathrm{F}$ & $\mathrm{F}$ & $\mathrm{F}$ & $\mathrm{M}$ \\
\hline 70 & $\mathrm{M}$ & $\mathrm{F}$ & $\mathrm{VF}$ & $\mathrm{VF}$ & $\mathrm{F}$ \\
\hline 71 & $\mathrm{M}$ & VF & $\mathrm{VN}$ & $\mathrm{S}$ & $\mathrm{M}$ \\
\hline 72 & $\mathrm{M}$ & VF & $\mathrm{N}$ & $S$ & $\mathrm{M}$ \\
\hline 73 & $\mathrm{M}$ & VF & $\mathrm{M}$ & $\mathrm{M}$ & $\mathrm{M}$ \\
\hline 74 & $\mathrm{M}$ & VF & $\mathrm{F}$ & $\mathrm{F}$ & $\mathrm{M}$ \\
\hline 75 & $\mathrm{M}$ & $\mathrm{VF}$ & VF & VF & $\mathrm{F}$ \\
\hline 76 & $\mathrm{~F}$ & $\mathrm{VN}$ & $\mathrm{VN}$ & VS & $\mathrm{F}$ \\
\hline 77 & $\mathrm{~F}$ & $\mathrm{VN}$ & $\mathrm{N}$ & VS & $\mathrm{F}$ \\
\hline 78 & $\mathrm{~F}$ & $\mathrm{VN}$ & $\mathrm{M}$ & VS & $\mathrm{F}$ \\
\hline 79 & $\mathrm{~F}$ & $\mathrm{VN}$ & $\mathrm{F}$ & $\mathrm{VS}$ & $\mathrm{F}$ \\
\hline
\end{tabular}

Julianto R B 


\begin{tabular}{|c|c|c|c|c|c|}
\hline 80 & F & VN & VF & F & S \\
\hline 81 & F & $\mathrm{N}$ & VN & $S$ & F \\
\hline 82 & $F$ & $\mathrm{~N}$ & $\mathrm{~N}$ & $S$ & $F$ \\
\hline 83 & F & $\mathrm{N}$ & $\mathrm{M}$ & $S$ & F \\
\hline 84 & $\mathrm{~F}$ & $\mathrm{~N}$ & $\mathrm{~F}$ & $S$ & $\mathrm{~F}$ \\
\hline 85 & F & $\mathrm{N}$ & VF & $\mathrm{M}$ & VS \\
\hline 86 & $\mathrm{~F}$ & $\mathrm{M}$ & VN & $S$ & $\mathrm{M}$ \\
\hline 87 & $\mathrm{~F}$ & $\mathrm{M}$ & $\mathrm{N}$ & $\mathrm{S}$ & M \\
\hline 88 & $\mathrm{~F}$ & $\mathrm{M}$ & $\mathrm{M}$ & $\mathrm{M}$ & $\mathrm{F}$ \\
\hline 89 & $\mathrm{~F}$ & $\mathrm{M}$ & $\mathrm{F}$ & $\mathrm{M}$ & $\mathrm{F}$ \\
\hline 90 & $\mathrm{~F}$ & $\mathrm{M}$ & $\mathrm{VF}$ & $\mathrm{F}$ & M \\
\hline 91 & F & $\mathrm{F}$ & VN & $S$ & $\mathrm{M}$ \\
\hline 92 & $\mathrm{~F}$ & $\mathrm{~F}$ & $\mathrm{~N}$ & $S$ & $\mathrm{M}$ \\
\hline 93 & $\mathrm{~F}$ & $\mathrm{~F}$ & $\mathrm{M}$ & $\mathrm{M}$ & $\mathrm{F}$ \\
\hline 94 & $\mathrm{~F}$ & $\mathrm{~F}$ & F & $\mathrm{F}$ & $\mathrm{F}$ \\
\hline 95 & $\mathrm{~F}$ & $F$ & VF & VF & $\mathrm{F}$ \\
\hline 96 & $\mathrm{~F}$ & VF & $\mathrm{VN}$ & $S$ & $\mathrm{~F}$ \\
\hline 97 & $\mathrm{~F}$ & VF & $\mathrm{N}$ & $S$ & $F$ \\
\hline 98 & $\mathrm{~F}$ & VF & M & $\mathrm{M}$ & $\mathrm{F}$ \\
\hline 99 & $\mathrm{~F}$ & $\mathrm{VF}$ & $F$ & $\mathrm{~F}$ & $F$ \\
\hline 100 & $\mathrm{~F}$ & VF & VF & VF & $\mathrm{F}$ \\
\hline 101 & $\mathrm{VF}$ & $\mathrm{VN}$ & VN & $\mathrm{S}$ & $\mathrm{F}$ \\
\hline 102 & $\mathrm{VF}$ & $\mathrm{VN}$ & $\mathrm{N}$ & $\mathrm{S}$ & $\mathrm{F}$ \\
\hline 103 & $\mathrm{VF}$ & $\mathrm{VN}$ & $\mathrm{M}$ & $S$ & $\mathrm{~F}$ \\
\hline 104 & $\mathrm{VF}$ & VN & $\mathrm{F}$ & $\mathrm{S}$ & $\mathrm{F}$ \\
\hline 105 & $\mathrm{VF}$ & $\mathrm{VN}$ & $\mathrm{VF}$ & $S$ & $\mathrm{~F}$ \\
\hline 106 & $\mathrm{VF}$ & $\mathrm{N}$ & VN & $\mathrm{VS}$ & $\mathrm{M}$ \\
\hline 107 & $\mathrm{VF}$ & $\mathrm{N}$ & $\mathrm{N}$ & $\mathrm{VS}$ & $\mathrm{M}$ \\
\hline 108 & $\mathrm{VF}$ & $\mathrm{N}$ & $\mathrm{M}$ & $\mathrm{VS}$ & $\mathrm{M}$ \\
\hline 109 & $\mathrm{VF}$ & $\mathrm{N}$ & $\mathrm{F}$ & $\mathrm{VS}$ & $\mathrm{M}$ \\
\hline 110 & VF & $\mathrm{N}$ & VF & VS & M \\
\hline 111 & $\mathrm{VF}$ & $\mathrm{M}$ & $\mathrm{VN}$ & $S$ & $\mathrm{M}$ \\
\hline 112 & VF & $\mathrm{M}$ & $\mathrm{N}$ & $\mathrm{S}$ & $\mathrm{M}$ \\
\hline 113 & VF & $\mathrm{M}$ & $\mathrm{M}$ & $\mathrm{M}$ & $\mathrm{F}$ \\
\hline No. & Left & Center & Right & MTRKi & MTRKa \\
\hline 114 & VF & $\mathrm{M}$ & $\mathrm{F}$ & $\mathrm{M}$ & $\mathrm{F}$ \\
\hline 115 & $\mathrm{VF}$ & $\mathrm{M}$ & VF & $\mathrm{M}$ & $\mathrm{F}$ \\
\hline 116 & $\mathrm{VF}$ & $\mathrm{F}$ & $\mathrm{VN}$ & $S$ & $\mathrm{~F}$ \\
\hline 117 & $\mathrm{VF}$ & $\mathrm{F}$ & $\mathrm{N}$ & $S$ & $\mathrm{~F}$ \\
\hline 118 & $\mathrm{VF}$ & $\mathrm{F}$ & $\mathrm{M}$ & $\mathrm{F}$ & VF \\
\hline 119 & $\mathrm{VF}$ & $\mathrm{F}$ & $\mathrm{F}$ & $\mathrm{F}$ & VF \\
\hline 120 & $\mathrm{VF}$ & $\mathrm{F}$ & $\mathrm{VF}$ & $\mathrm{F}$ & $\mathrm{F}$ \\
\hline 121 & VF & VF & VN & M & $\mathrm{F}$ \\
\hline 122 & VF & $\mathrm{VF}$ & $\mathrm{N}$ & $\mathrm{M}$ & $\mathrm{F}$ \\
\hline 123 & $\mathrm{VF}$ & VF & M & $\mathrm{F}$ & VF \\
\hline 124 & VF & $\mathrm{VF}$ & $\mathrm{F}$ & $\mathrm{F}$ & $\mathrm{VF}$ \\
\hline 125 & VF & VF & $\mathrm{VF}$ & $\mathrm{F}$ & $\mathrm{F}$ \\
\hline
\end{tabular}

Seperti yang terlihat pada Tabel 3.1 rule evaluation motor kanan dan kiri akan bergerak sesuai input dari masing-masing sensor. Dari 5 fuzzy input, akan memberikan output kecepatan motor yang diberi label Back (B), Very Slow (VS), Slow (S), Medium (M), Fast (F), Very Fast (VF)

Proses terakhir dari fuzzy logic adalah defuzifikasi yaitu untuk menentukan suatu nilai crisp output. Suatu nilai fuzzy output yang berasal dari rule evaluation diambil kemudian dimasukkan ke dalam suatu membership function output. Motor akan bergerak berdasarkan pwm yang dikendalikan oleh driver motor yang mendapat input dari masing-masing sensor melaui Arduino untuk melalui medan yang akan dilalui oleh robot.

3.3 Perancangan Alat

3.3.1 Perancangan Perangkat Keras (Hardware)

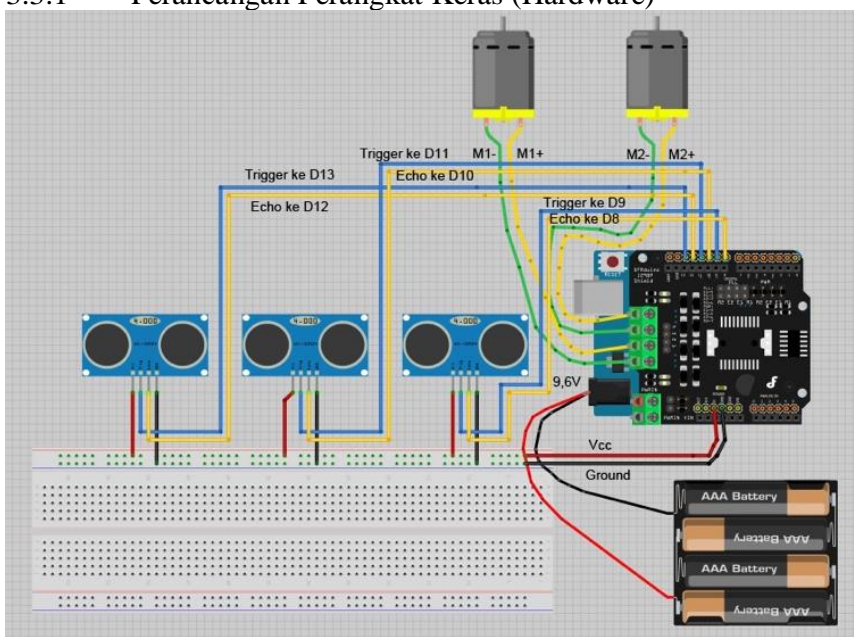

Gambar 3.4. Rangkaian Keseluruhan Robot Tank

Sensor ultrasonik HC-SR04 mempunyai 4 kaki yaitu : power supply, ground, trigger pin, dan echo pin. Trigger pin dari sensor kiri terhubung ke pin D13, Echo pin terhubung ke pin D12, Trigger pin dari sensor depan terhubung ke pin D11, Echo pin terhubung ke pin D10, dan Trigger pin dari sensor kanan terhubung ke pin D9, Echo pin terhubung ke pin D8, ini berarti mikrokontroler diatur sebagai output dan memberikan data ke sensor. Kaki Vcc dihubungkan ke sumber arus 5 volt. Dan kaki Gnd dihubungkan ke ground.

Arduino motor shield menggunakan driver H-bridge Chip L298P, yang mampu mendorong motor DC, dua fase atau empat fase stepper motor dengan maksimal Arus 2A. Driver motor digunakan untuk mengerakkan (generate) motor sehingga bekerja secara optimal. Optimal disini berarti dapat dikontrol sehingga mencapai gerak yang bagus pada motor.

Arduino Motor Shield terhubung secara mounted ke Arduino Uno. Pin digital 4,5,6 dan 7 digunakan sebagai output untuk pengendalian motor DC, dimana pin 5, 6 berfungsi untuk mengatur PWM (Pulse Width Modulation) motor.

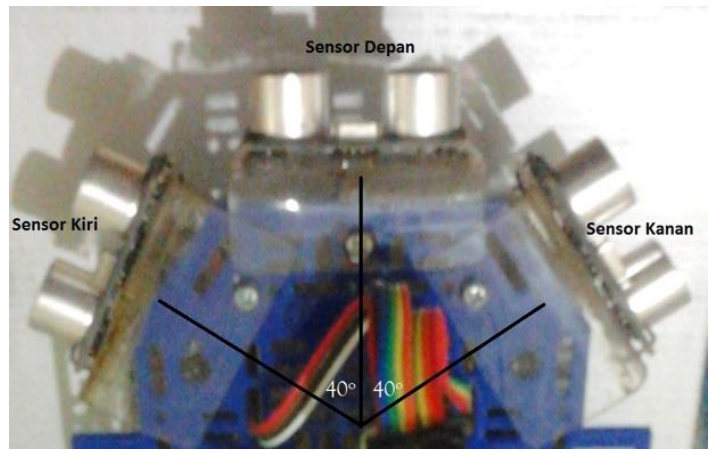

Gambar 3.5 Sudut Bacaan Sensor Ultrasonik 
Peletakan sensor ultrasonik berada pada bagian kiri, depan, dan kanan dengan perbedaan sudut masing-masing sensor sebesar $40^{\circ}$

Sensor depan akan membaca jarak halangan pada bagian depan, begitu juga dengan sensor kini dan kanan membaca jarak halangan di bagian kiri dan kanan. Sensor akan membaca jarak terjauh $80 \mathrm{~cm}$ dari posisi robot.

Sistem penggerak robot berasal dari motor DC yang memutar roda dengan belt tank. Masing-masing motor DC menggerakkan roda kiri dan kanan. Roda belakang dan depan terhubung oleh belt tank yang memiliki penyeimbang di tengah. Kelebihan dari sistem penggerak menggunakan roda belt tank adalah memungkinkan robot untuk melewati jalanan yang bergelombang dan sebagai penyeimbang saat terjadi perubahan sudut pergerakan robot. Hal ini terjadi karena konstruksi roda belt tank yang melengkung seperti perahu yang dapat melewati ketidakrataan jalan. Lengkungan di depan dan belakang berguna untuk penopang dan penyeimbang robot saat melewati perubahan sudut tempuh.

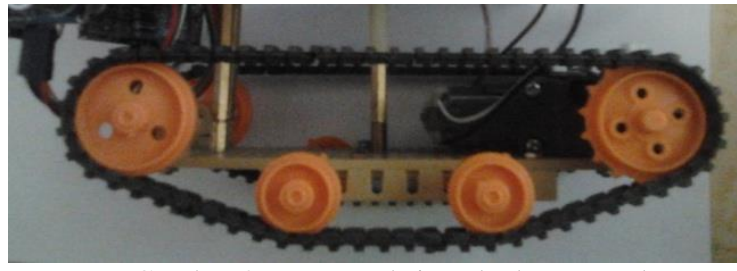

Gambar 3.6 Konstruksi Roda dengan Belt

\subsubsection{Perancangan Perangkat Lunak (Software)}

Kecepatan motor DC akan bereaksi terhadap perubahan jarak. Berbagai perubahan akan menghasilkan kecepatan motor DC yang berubah-ubah berdasarkan PWM. PWM akan diatur berdasarkan jarak halangan yang dideteksi melalui sensor ultrasonik dan pengendalian kecepatan motor DC melalui PWM inilah yang akan diatur dengan menggunakan logika fuzzy. Metoda logika fuzzy yang digunakan pada pengontrolan kecepatan robot tank ini adalah metode Sugeno. Metode Sugeno mampu menghasilkan komputasi yang efisien, sesuai untuk analisis matematis dan memiliki output linier atau konstan.

Pada metode ini diperlukan 4 tahapan untuk mendapatkan output, yaitu pembentukan himpunan fuzzy (fuzzyfikasi), basis pengetahuan, logika pengambil keputusan, dan penegasan (defuzzyfikasi). Komposisi aturan digunakan operator AND sedangkan untuk defuzzyfikasi menggunakan metode Singleton. Fuzzifikasi

Komponen fuzzifikasi berfungsi untuk memetakan masukan data tegas ke dalam himpunan Fuzzy menjadi nilai Fuzzy dari beberapa variabel linguistik masukan. Sinyal input dari sensor jarak yang berupa nilai tegas (crisp) difuzzifikasi menjadi himpunanhimpunan fuzzy VN ("Very Near"), N ("Near"), M ("Medium"),

F ("Far"), VF ("Very Far"). Himpunan masing-masing memiliki nilai sebagai berikut :

$\mathrm{VN}: 0-30 \mathrm{~cm}$

$\mathrm{N} \quad: 20-40 \mathrm{~cm}$

M : $30-50 \mathrm{~cm}$

F : : 40-60 cm

VF : $50-80 \mathrm{~cm}$
Pada proses fuzzyfikasi ini terdapat 2 macam kurva yakni kurva segitga dan kurva trapesium.

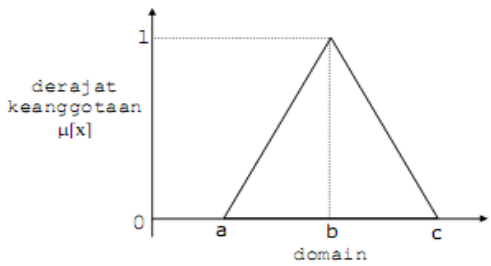

Gambar 3.7 Kurva Segitiga

Fungsi keanggotaan kurva segitiga :

$\mu(x)=\left\{\begin{aligned} 0, & x \leq a \text { atau } x \geq c \\ \frac{x-a}{b-a}, & a \leq x \leq b \\ \frac{b-x}{c-b}, & b \leq x \leq c\end{aligned}\right.$

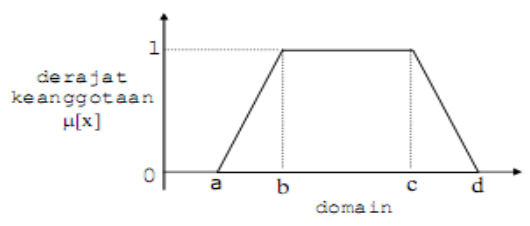

Gambar 3.8 Kurva Trapesium

Fungsi keanggotaan kurva trapezium :

$$
\mu(x)=\left\{\begin{aligned}
0, & x \leq a \text { atau } x \geq d \\
\frac{x-a}{b-a}, & a \leq x \leq b \\
1, & b \leq x \leq c \\
\frac{d-x}{d-c}, & x \geq d
\end{aligned}\right.
$$

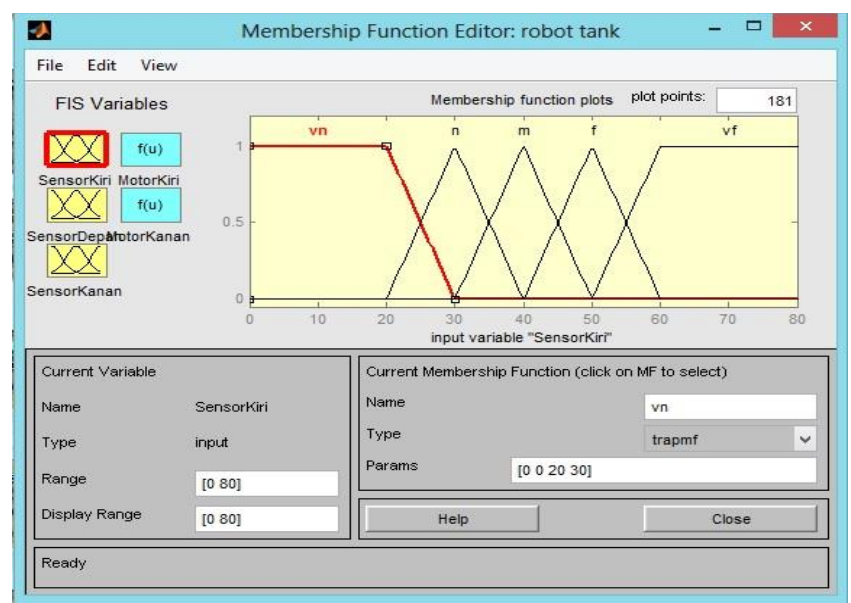

Gambar 3.9 Membership Function Input Variabel Jarak (cm)

\section{Rule Evaluation}

Untuk mendapatkan nilai fuzzy yang diinginkan, diperlukan perancangan fungsi keanggotaan untuk variabel masukan dan keluaran, pendefinisian semesta pembicaraan, dan penentuan variable linguistik setiap variabel masukan dan keluaran. Basis aturan kendali fuzzy adalah kumpulan aturanaturan kendali Fuzzy yang dibuat berdasarkan pengetahuan manusia dalam pengendalian suatu sistem, aturan ini berbentuk 'JIKA-MAKA' (IF -THEN) yang didasarkan pada pengetahuan manusia untuk mengolah variabel masukan sehingga menghasilkan variabel keluaran dalam bentuk himpunan Fuzzy. Rule evaluation dapat dilihat pada table 3.1

3. Defuzzifikasi

Defuzzifikasi adalah proses pengubahan besaran fuzzy yang disajikan dalam himpunan Fuzzy ke sinyal yang bersifat bukan fuzzy. Strategi defuzzifikasi ditujukan untuk menghasilkan 
suatu aksi kontrol bukan fuzzy (crisp output) yang paling tepat dalam merepresentasikan kemungkinan distribusi aksi kontrol fuzzy yang telah dihitung. Salah satu metode defuzzifikasi adalah metode COG (Center of Gravity). Nilai keluaran tegas metode COG (Center of Gravity) adalah jumlah dari hasil kali keluaran fuzzy untuk setiap himpunan fuzzy keluaran dengan posisi singleton pada sumbu x setiap himpunan fuzzy keluaran dibagi dengan jumlah keluaran fuzzy untuk setiap himpunan fuzzy keluaran atau dapat dirumuskan :

$$
C O G=\frac{\sum_{i}\left(\text { Fuzzy Output }_{i}\right) \times\left({\text { Posisi Singleton di } \left.X \text { axis }_{i}\right)}^{-}\right.}{\sum_{i}\left(\text { Fuzzy Output }_{i}\right)}
$$

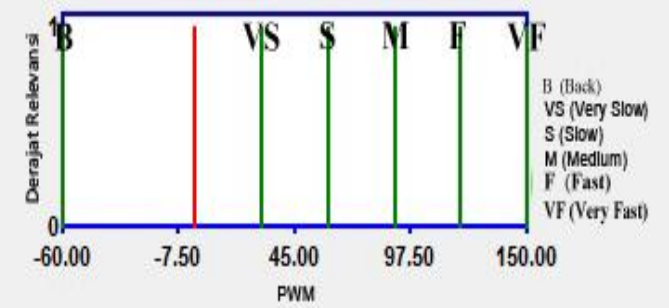

Gambar 3.10 Membership Function Output Variabel Kecepatan (PWM)

\section{ANALISA DAN PENGUJIAN}

4.1 Analisa Perangkat Keras (Hardware)

4.1.1 Analisa dan Pengujian Sensor Ultrasonik HC-SR04

Untuk menghitung jarak yang terukur dari waktu terima sensor dapat menggunakan persamaan berikut ini :

$$
S=\frac{\left(\frac{t}{V}\right)}{2}
$$

Di mana:

$$
\begin{array}{ll}
\mathrm{V} & =\text { adalah kecepatan suara } 29,034 \mu \mathrm{s} / \mathrm{cm} \\
\mathrm{t} & =\text { adalah lebar pulsa }(\mu \mathrm{s}) \\
\mathrm{s} & =\text { adalah jarak }(\mathrm{cm})
\end{array}
$$

Pengujian sensor ultrasonik dilakukan dengan mengukur hasil pengukuran antara jarak sensor dengan halangan di depannya. Adapun perbandingan dari hasil pengukuran dapat dilihat pada tabel dibawah ini :

Tabel 4.1 Tabel Hasil Perbandingan Pengukuran Jarak

\begin{tabular}{|c|c|}
\hline Pembacaan dengan mistar & Pembacaan HC-SR04 \\
\hline $10 \mathrm{~cm}$ & $9 \mathrm{~cm}$ \\
\hline $20 \mathrm{Cm}$ & $19 \mathrm{~cm}$ \\
\hline $30 \mathrm{Cm}$ & $29 \mathrm{~cm}$ \\
\hline $40 \mathrm{Cm}$ & $39 \mathrm{~cm}$ \\
\hline $50 \mathrm{Cm}$ & $48 \mathrm{~cm}$ \\
\hline $60 \mathrm{Cm}$ & $58 \mathrm{~cm}$ \\
\hline $70 \mathrm{Cm}$ & $67 \mathrm{~cm}$ \\
\hline $80 \mathrm{Cm}$ & $77 \mathrm{~cm}$ \\
\hline
\end{tabular}

Dari data diatas didapat persentase error hasil pengukuran sensor dengan hasil pengukuran mistar (sebenarnya). $\%$ kesalahan $=\left|\frac{\text { Nilaisebenarnya-nilaipembacaansensor }}{\text { nilaisebenarnya }}\right| \times 100 \%$

$$
\begin{aligned}
& =\left|\frac{10 \mathrm{~cm}-9 \mathrm{~cm}}{10 \mathrm{~cm}}\right| \times 100 \%=10 \% \\
& =\left|\frac{20 \mathrm{~cm}-19 \mathrm{~cm}}{20 \mathrm{~cm}}\right| \times 100 \%=5 \% \\
& =\left|\frac{30 \mathrm{~cm}-29 \mathrm{~cm}}{30 \mathrm{~cm}}\right| \times 100 \%=3,33 \% \\
& =\left|\frac{40 \mathrm{~cm}-39 \mathrm{~cm}}{40 \mathrm{~cm}}\right| \times 100 \%=2,5 \% \\
& =\left|\frac{50 \mathrm{~cm}-48 \mathrm{~cm}}{50 \mathrm{~cm}}\right| \times 100 \%=4 \% \\
& =\left|\frac{60 \mathrm{~cm}-58 \mathrm{~cm}}{60 \mathrm{~cm}}\right| \times 100 \%=3,33 \% \\
& =\left|\frac{70 \mathrm{~cm}-67 \mathrm{~cm}}{70 \mathrm{~cm}}\right| \times 100 \%=4,29 \% \\
& =\left|\frac{80 \mathrm{~cm}-77 \mathrm{~cm}}{80 \mathrm{~cm}}\right| \times 100 \%=3,75 \% \\
\text { Rata- rata } & =\frac{10+5+3,33+2,5+4+3,33+4,29+3,75}{8}=4,525 \%
\end{aligned}
$$

Melihat hasil rata-rata kesalahan pembacaan sensor yang bernilia 4,525 \% saja. Maka dapat disimpulkan bahwa pembacaan jarak oleh sensor ultrasonik sudah bekerja dengan baik.

4.1.2 Analisa dan Pengujian Driver Motor

Tabel 4.2 Tabel Pengujian Driver Motor

\begin{tabular}{|l|l|l|l|l|l|}
\hline E1 & M1 & $\begin{array}{l}\text { Keadaan } \\
\text { Motor }\end{array}$ & E2 & M2 & $\begin{array}{l}\text { Keadaan } \\
\text { Motor }\end{array}$ \\
\hline LOW & LOW & $\begin{array}{l}\text { Motor 1 } \\
\text { Mati }\end{array}$ & LOW & LOW & $\begin{array}{l}\text { Motor 2 } \\
\text { Mati }\end{array}$ \\
\hline HIGH & HIGH & $\begin{array}{l}\text { Motor 1 } \\
\text { Mundur }\end{array}$ & HIGH & HIGH & $\begin{array}{l}\text { Motor 2 } \\
\text { Mundur }\end{array}$ \\
\hline HIGH & LOW & $\begin{array}{l}\text { Motor 1 } \\
\text { Maju }\end{array}$ & HIGH & LOW & $\begin{array}{l}\text { Motor 2 } \\
\text { Maju }\end{array}$ \\
\hline PWM & $\mathrm{X}$ & $\begin{array}{l}\text { PWM } \\
\text { kontrol }\end{array}$ & PWM & X & $\begin{array}{l}\text { PWM } \\
\text { kontrol }\end{array}$ \\
\hline
\end{tabular}

Dari tabel diatas dapat dijelaskan bahwa motor akan bergerak sesuai dengan data yang diberikan. Jika data yang diberikan adalah LOW, LOW maka motor tidak bergerak atau mati. Hal ini dikarenakan keluaran dari IC ini akan bernilai 0 (nol) atau tidak ada tegangan yang keluar dari IC tersebut. Jika data yang diberikan adalah HIGH, HIGH maka motor akan bergerak mundur. Dan jika data yang diberikan adalah HIGH, LOW maka motor akan bergerak maju. PWM akan bergerak sesuai dengan nilai analogWrite() yang diberikan.

\subsection{Analisa Perangkat Lunak (Software)}

\subsubsection{Analisa Fuzzy Logic Pada Pergerakan Robot Tank}

+ Belok kanan

Sensor kiri membaca nilai $19 \mathrm{~cm}$, Sensor tengah membaca nilai $19 \mathrm{~cm}$, dan sensor kanan membaca nilai $53 \mathrm{~cm}$. Nilai 19 pada sensor kiri masuk ke dalam himpunan VN "Very Near". Nilai 19 pada sensor tengah juga termasuk ke dalam himpunan VN "Very Near". Sedangkan nilai 53 pada sensor kanan termasuk ke dalam 2 himpunan yakni $F$ "Far" dan VF 
"Very Far". Dengan demikian nilai 19,19,53 termasuk ke dalam 2 rule yang bersinggungan yaitu :

- Jika sensor kiri vn " very near", sensor tengah vn "very near", sensor kanan $f$ "far" maka motor kiri $f$ "fast" dan motor kanan vs "very slow".

- Jika sensor kiri vn " very near", sensor tengah vn " very near", sensor kanan vf "very far" maka motor kiri f "fast" dan motor kanan s "slow".

Berdasarkan rule tersebut maka pada rule pertama kecepatan motor kiri F "Fast" dan kanan VS "Very Slow" dimana nilai crisp output $\mathrm{F}=120, \mathrm{VS}=30$. Begitu juga dengan rule kedua kecepatan motor kiri F "Fast" dan kanan S "Slow" dimana nilai crisp output $\mathrm{F}=120, \mathrm{~S}=60$.

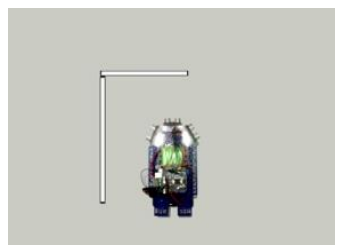

Gambar 4.1 Keadaan Belok Kanan

Untuk rule pertama 19,19,53 nilai 53 berada pada nilai $\mathrm{F}$, maka dicari terlebih dahulu nilai derajat keanggotaan minimal dari ketiga sensor. Nilai minimal diambil karena menggunakan logika AND. Sensor kiri dan tengah sudah memiliki nilai 1, sensor kanan yang dicari terlebih dahulu derajat relevansi dari nilai crisp 53 sebagai berikut :

$\Pi \mathrm{x}=(60-53) /(60-50)=0,7$

Pada penggalan program dapat dilihat bahwa nilai 53 untuk rule 1 masuk ke penggalan program float far dimana jarak $>50 \& \&$ jarak $<=60$

Karena nilai sensor kiri dan tengah 1, maka minimal yang didapat adalah 0,7 untuk rule 1 . Pencarian nilai minimal didapat dari penggalan program pencarian nilai minimal dari 125 rule

Untuk rule kedua 19,19,53 nilai 53 berada pada nilai VF, maka dicari terlebih dahulu nilai derajat keanggotaan minimal dari ketiga sensor. Sensor kiri dan tengah sudah memiliki nilai 1 , sensor kanan dicari terlebih dahulu derajat relevansi dari nilai crisp 53 sebagai berikut :

$\Pi \mathrm{x}=(53-50) /(60-50)=0,3$

Nilai minimal yang didapat adalah 0,3 untuk rule 2

Maka nilai Center of Gravity nya adalah :

$$
\begin{aligned}
& C O G=\frac{0,7 \times 120+0,3 \times 120}{1}=120 \quad \text { (untuk PWM kiri) } \\
& C O G=\frac{0,7 \times 30+0,3 \times 60}{1}=39 \quad \text { (untuk PWM kanan) }
\end{aligned}
$$$$
+ \text { Belok kiri }
$$

Sensor kiri membaca nilai $53 \mathrm{~cm}$, Sensor tengah membaca nilai $24 \mathrm{~cm}$, dan sensor kanan membaca nilai $19 \mathrm{~cm}$. Nilai 53 pada sensor kiri masuk ke dalam 2 himpunan yakni $F$ "Far" dan VF "Very Far". Nilai 24 pada sensor tengah juga termasuk ke dalam 2 himpunan yakni VN "Very Near" dan N "Near". Sedangkan nilai 19 pada sensor kanan termasuk ke dalam himpunan VN "Very Near". Dengan demikian nilai 53,24,19 termasuk ke dalam 4 rule yang bersinggungan yaitu :

- Jika sensor kiri f "far", sensor tengah vn "very near", sensor kanan vn "very near" maka motor kiri vs "very slow" dan motor kanan $\mathrm{f}$ "fast".

- Jika sensor kiri f "far", sensor tengah n "near", sensor kanan vn "very near" maka motor kiri s "slow" dan motor kanan $f$ "fast".
- Jika sensor kiri vf "very far", sensor tengah vn "very near", sensor kanan vn "very near" maka motor kiri s "slow" dan motor kanan f "fast".

- Jika sensor kiri vf "very far", sensor tengah n "near", sensor kanan vn "very near" maka motor kiri vs "very slow" dan motor kanan m "medium".

Berdasarkan rule tersebut maka pada rule pertama kecepatan motor kiri VS "Very Slow" dan kanan F "Fast" dimana nilai crisp output VS $=30, F=120$. Rule kedua kecepatan motor kiri S "Slow" dan kanan F "Fast" dimana nilai crisp output $\mathrm{S}=$ $60, F=120$. Rule ketiga kecepatan motor kiri S "Slow" dan kanan F "Fast" dimana nilai crisp output $S=60, F=120$. Begitu juga dengan rule keempat kecepatan motor kiri VS "Very Slow" dan kanan M "Medium" dimana nilai crisp output VS $=30, \mathrm{M}=90$.

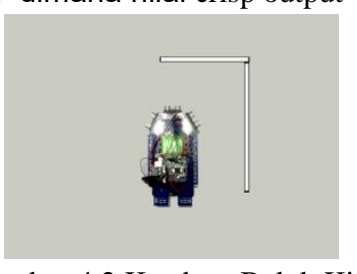

\section{Gambar 4.2 Keadaan Belok Kiri}

Untuk rule pertama 53,24,19 nilai 53 berada pada nilai F, dan nilai 24 berada pada nilai VN, maka dicari terlebih dahulu nilai derajat keanggotaan minimal dari ketiga sensor. Nilai minimal diambil karena menggunakan logika AND. Sensor kanan sudah memiliki nilai 1 , sensor kiri dan tengah dicari terlebih dahulu derajat relevansinya. Sensor kiri dengan nilai crisp 53 derajat relevansinya sebagai berikut :

$\Pi \mathrm{x}=(60-53) /(60-50)=0,7$

Sensor tengah dengan nilai crisp 24 derajat relevansinya sebagai berikut :

$\Pi \mathrm{x}=(30-24) /(30-20)=0,6$

Karena nilai kanan 1, maka minimal yang didapat adalah 0,6 untuk rule 1

Untuk rule kedua 53,24,19 nilai 53 berada pada nilai $\mathrm{F}$, dan nilai 24 berada pada nilai $\mathrm{N}$, maka dicari terlebih dahulu nilai derajat keanggotaan minimal dari ketiga sensor. Sensor kanan sudah memiliki nilai 1 , sensor kiri dan tengah dicari terlebih dahulu derajat relevansinya. Sensor kiri dengan nilai crisp 53 derajat relevansinya sebagai berikut :

$\Pi \mathrm{x}=(60-53) /(60-50)=0,7$

Sensor tengah dengan nilai crisp 24 derajat relevansinya sebagai berikut :

$\Pi \mathrm{x}=(24-20) /(30-20)=0,4$

Karena nilai kanan 1 , maka minimal yang didapat adalah 0,4 untuk rule 2

Untuk rule ketiga 53,24,19 nilai 53 berada pada nilai $\mathrm{VF}$, dan nilai 24 berada pada nilai VN, maka dicari terlebih dahulu nilai derajat keanggotaan minimal dari ketiga sensor. Sensor kanan sudah memiliki nilai 1, sensor kiri dan tengah dicari terlebih dahulu derajat relevansinya. Sensor kiri dengan nilai crisp 53 derajat relevansinya sebagai berikut :

$\Pi \mathrm{x}=(53-50) /(60-50)=0,3$

Sensor tengah dengan nilai crisp 24 derajat relevansinya sebagai berikut :

$\Pi \mathrm{x}=(30-24) /(30-20)=0,6$

Karena nilai kanan 1 , maka minimal yang didapat adalah 0,3 untuk rule 3

Untuk rule keempat 53,24,19 nilai 53 berada pada nilai VF, dan nilai 24 berada pada nilai $\mathrm{N}$, maka dicari terlebih dahulu 
nilai derajat keanggotaan minimal dari ketiga sensor. Sensor kanan sudah memiliki nilai 1 , sensor kiri dan tengah dicari terlebih dahulu derajat relevansinya. Sensor kiri dengan nilai crisp 53 derajat relevansinya sebagai berikut :

$\Pi \mathrm{x}=(53-50) /(60-50)=0,3$

Sensor tengah dengan nilai crisp 24 derajat relevansinya sebagai berikut :

$\Pi \mathrm{x}=(24-20) /(30-20)=0,4$

Karena nilai kanan 1, maka minimal yang didapat adalah 0,3 untuk rule 4

Maka nilai Center of Gravity nya adalah :

$$
\begin{array}{r}
C O G=\frac{0,6 \times 30+0,4 \times 60+0,3 \times 60+0,3 \times 30}{1,6} \\
=43,1 \quad(\text { untuk PWM kiri) }
\end{array}
$$

\subsubsection{Pengujian Jarak Halangan Terhadap Arah} Gerakan Robot Tank

Tabel 4.3 Tabel Pengujian Jarak Halangan terhadap Arah Gerakan Robot Tank.
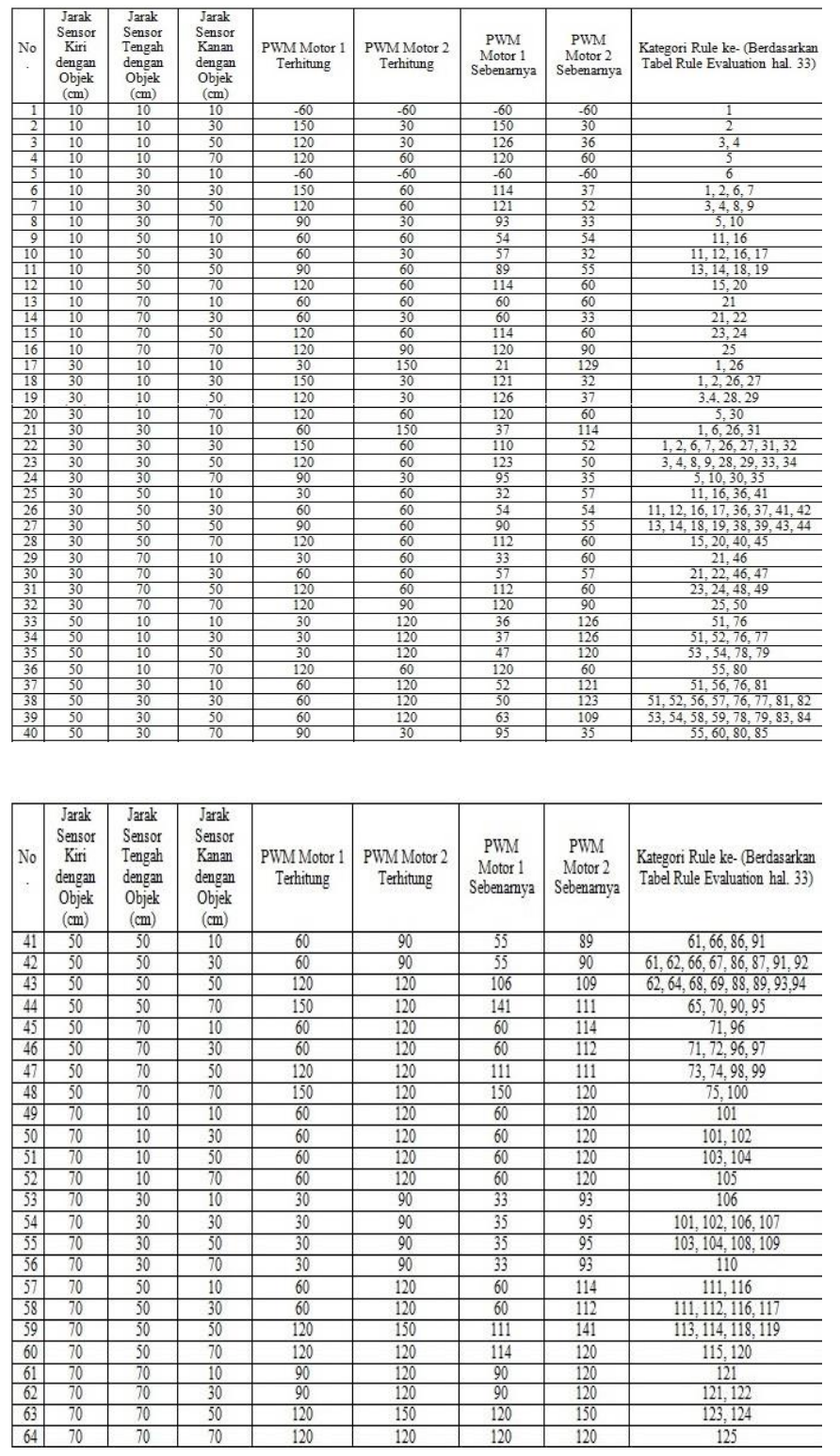

16 Julianto R B
Pengujian dilakukan hingga 64 kali untuk melihat karakteristik dari kendali fuzzy yang digunakan. Pada tabel terlihat perbedaan keluaran PWM untuk pengendalian motor DC tergantung pada jarak halangan yang terbaca oleh masing-masing sensor. Arah belokan robot akan makin tajam apabila jarak rintangan semakin dekat. Kondisi robot yang sangat dekat dengan halangan membuat robot melakukan gerakan mundur. Hal ini terjadi untuk menghindari benturan ketika robot sudah sangat dekat dengan halangan pada sensor kiri, depan, dan kanan. Nilai PWM sebenarnya dengan nilai PWM terhitung mengalami sedikit perbedaan dikarenakan pembacaan jarak oleh sensor ultrasonik yang mengalami sedikit perbedaan.. Secara keseluruhan pergerakan robot telah berjalan seperti yang diharapkan.

\subsubsection{Pengujian Keberhasilan Robot Tank \\ Menghindari Halangan}

Pengujian dilakukan dengan meletakkan robot tank dengan berbagai jarak dalam $(\mathrm{cm})$ terhadap halangan dan berbagai kondisi sudut halangan. Nilai sudut di dapat dari perhitungan menggunakan busur. Data yang ditampilkan berupa keberhasilan robot tank menghindari halangan dari berbagai macam sudut.

Pengujian bagian pertama dilakukan dengan jarak robot tank terhadap halangan di depan $10 \mathrm{~cm}$, arah belokan robot ke kanan, dan sudut halangan masing-masing $150^{\circ}, 120^{\circ}, 90^{\circ}, 60^{\circ}$, $30^{\circ}$. Robot tank berhasil melewati halangan pada sudut $150^{\circ}$, $120^{\circ}, 90^{\circ}, 60^{\circ}$. Pada sudut $30^{\circ}$ robot mengalami benturan dengan halangan, ini dikarenakan pendeknya jarak putar robot dan kecilnya sudut yang harus dilalui tidak sebanding dengan panjang dan lebar robot. Pada arah belokan robot ke kiri. Robot tank berhasil melewati halangan pada sudut $150^{\circ}, 120^{\circ}, 90^{\circ}$. Pada sudut $60^{\circ}, 30^{\circ}$ robot mengalami benturan dengan halangan, ini terjadi karena sensor ultrasonik kanan dan depan membaca jarak dekat, sensor kiri juga membaca jarak dekat. Hal ini berakibat pada putaran robot yang cenderung ke kanan dan dapat berakibat pada benturan terhadap halangan. Rule yang telah di set memungkinkan robot untuk lebih cenderung melakukan putaran ke kanan apabila semua jarak yang terbaca oleh sensor ultrasonik masuk ke kategori dekat.

Tabel. 4.4 Tabel Keberhasilan Robot TankMenghindari Halangan 


\begin{tabular}{|c|c|c|c|c|}
\hline No. & Arah Belokan & $\begin{array}{c}\text { Jarak dengan } \\
\text { Halangan } \\
(\mathrm{cm})\end{array}$ & Sudut & Keberhasilan \\
\hline \multirow{2}{*}{$\frac{1}{2}$} & \multirow[t]{5}{*}{ Kanan } & \multirow{10}{*}{15} & $150^{\circ}$ & $\sqrt{ }$ \\
\hline & & & $120^{\circ}$ & $\sqrt{ }$ \\
\hline 3 & & & $90^{\circ}$ & $\sqrt{ }$ \\
\hline 4 & & & $60^{\circ}$ & $\sqrt{1}$ \\
\hline 5 & & & $30^{\circ}$ & $\mathrm{x}$ \\
\hline 6 & \multirow[t]{5}{*}{ Kiri } & & $150^{\circ}$ & $\sqrt{1}$ \\
\hline 7 & & & $120^{\circ}$ & $\sqrt{1}$ \\
\hline 8 & & & $90^{\circ}$ & $\sqrt{ }$ \\
\hline 9 & & & $60^{\circ}$ & $\mathrm{x}$ \\
\hline 10 & & & $30^{\circ}$ & $\mathrm{x}$ \\
\hline 11 & \multirow[t]{5}{*}{ Kanan } & \multirow[t]{10}{*}{30} & $150^{\circ}$ & $\sqrt{ }$ \\
\hline 12 & & & $120^{\circ}$ & $\sqrt{ }$ \\
\hline 13 & & & $90^{\circ}$ & $\sqrt{1}$ \\
\hline 14 & & & $60^{\circ}$ & $\sqrt{1}$ \\
\hline 15 & & & $30^{\circ}$ & $\sqrt{ }$ \\
\hline 16 & \multirow[t]{5}{*}{ Kiri } & & $150^{\circ}$ & $\sqrt{2}$ \\
\hline 17 & & & $120^{\circ}$ & $\sqrt{ }$ \\
\hline 18 & & & $90^{\circ}$ & $\sqrt{1}$ \\
\hline 19 & & & $60^{\circ}$ & $\mathrm{x}$ \\
\hline 20 & & & $30^{\circ}$ & $\mathrm{x}$ \\
\hline 21 & \multirow[t]{5}{*}{ Kanan } & \multirow[t]{10}{*}{50} & $150^{\circ}$ & $\sqrt{ }$ \\
\hline 22 & & & $120^{\circ}$ & $\sqrt{ }$ \\
\hline 23 & & & $90^{\circ}$ & $\sqrt{1}$ \\
\hline 24 & & & $60^{\circ}$ & $\sqrt{1}$ \\
\hline 25 & & & $30^{\circ}$ & $\sqrt{ }$ \\
\hline 26 & \multirow[t]{5}{*}{ Kiri } & & $150^{\circ}$ & $\sqrt{ }$ \\
\hline 27 & & & $120^{\circ}$ & $\sqrt{ }$ \\
\hline 28 & & & $90^{\circ}$ & $\sqrt{1}$ \\
\hline 29 & & & $60^{\circ}$ & $\sqrt{1}$ \\
\hline 30 & & & $30^{\circ}$ & $\mathrm{x}$ \\
\hline \multirow[t]{2}{*}{ No. } & & Jarak dengan & & \\
\hline & Arah Belokan & $\begin{array}{c}\text { Halangan } \\
(\mathrm{cm})\end{array}$ & Sudut & Keberhasilan \\
\hline 31 & \multirow[t]{5}{*}{ Kanan } & \multirow[t]{10}{*}{70} & $150^{\circ}$ & $\sqrt{1}$ \\
\hline 32 & & & $120^{\circ}$ & $\sqrt{ }$ \\
\hline 33 & & & $90^{\circ}$ & $\sqrt{1}$ \\
\hline 34 & & & $60^{\circ}$ & $\sqrt{1}$ \\
\hline 35 & & & $30^{\circ}$ & $\sqrt{1}$ \\
\hline 36 & \multirow[t]{5}{*}{ Kiri } & & $150^{\circ}$ & $\sqrt{ }$ \\
\hline 37 & & & $120^{\circ}$ & $\sqrt{ }$ \\
\hline \begin{tabular}{|l|}
38 \\
\end{tabular} & & & $90^{\circ}$ & $\sqrt{1}$ \\
\hline \begin{tabular}{|l|}
39 \\
\end{tabular} & & & $60^{\circ}$ & $\sqrt{1}$ \\
\hline 40 & & & $30^{\circ}$ & $\mathrm{x}$ \\
\hline
\end{tabular}

Pengujian bagian kedua dilakukan dengan jarak robot tank terhadap halangan di depan $30 \mathrm{~cm}$, arah belokan robot ke kanan, dan sudut halangan masing-masing $150^{\circ}, 120^{\circ}, 90^{\circ}, 60^{\circ}$, $30^{\circ}$. Robot tank berhasil melewati halangan pada semua sudut. Dengan jarak yang cukup jauh, sudut $30^{\circ}$ yang pada percobaan pertama robot mengalami benturan dengan halangan telah dapat dilewati. Ini dikarekan robot tank punya waktu untuk melakukan putaran sedini mungkin agar badan robot tidak berbenturan dengan halangan. Pada arah belokan robot ke kiri. Robot tank berhasil melewati halangan pada sudut $150^{\circ}, 120^{\circ}, 90^{\circ}$. Pada sudut $60^{\circ}, 30^{\circ}$ robot mengalami benturan dengan halangan, ini terjadi karena sensor ultrasonik kanan dan depan membaca jarak dekat, sensor kiri juga membaca jarak dekat. Hal ini berakibat pada putaran robot yang cenderung ke kanan dan dapat berakibat pada benturan terhadap halangan.

Pengujian bagian ketiga dilakukan dengan jarak robot tank terhadap halangan di depan $50 \mathrm{~cm}$, arah belokan robot ke kanan, dan sudut halangan masing-masing $150^{\circ}, 120^{\circ}, 90^{\circ}, 60^{\circ}$, $30^{\circ}$. Robot tank berhasil melewati halangan pada semua sudut. Pada arah belokan robot ke kiri. Robot tank berhasil melewati halangan pada sudut $150^{\circ}, 120^{\circ}, 90^{\circ}, 60^{\circ}$. Dengan jarak yang cukup jauh, sudut $60^{\circ}$ yang pada percobaan pertama dan kedua robot mengalami benturan dengan halangan telah dapat dilewati. Ini dikarekan sensor kiri telah membaca jarak medium yang memungkinkan robot berbelok ke kiri dan robot tank punya waktu untuk melakukan putaran sedini mungkin agar badan robot tidak berbenturan dengan halangan. Pada sudut $30^{\circ}$ robot mengalami benturan dengan halangan, ini terjadi karena sensor ultrasonik kanan dan depan membaca jarak dekat, sensor kiri juga membaca jarak dekat. Hal ini berakibat pada putaran robot yang cenderung ke kanan dan dapat berakibat pada benturan terhadap halangan.

Pengujian bagian keempat dilakukan dengan jarak robot tank terhadap halangan di depan $70 \mathrm{~cm}$, arah belokan robot ke kanan, dan sudut halangan masing-masing $150^{\circ}, 120^{\circ}, 90^{\circ}, 60^{\circ}$, $30^{\circ}$. Robot tank berhasil melewati halangan pada semua sudut. Pada arah belokan robot ke kiri. Robot tank berhasil melewati halangan pada sudut $150^{\circ}, 120^{\circ}, 90^{\circ}, 60^{\circ}$. Dengan jarak yang jauh, sudut $60^{\circ}$ yang pada percobaan pertama dan kedua robot mengalami benturan dengan halangan telah dapat dilewati. Ini dikarekan sensor kiri telah membaca jarak medium yang memungkinkan robot berbelok ke kiri dan robot tank punya waktu untuk melakukan putaran sedini mungkin agar badan robot tidak berbenturan dengan halangan. Pada sudut $30^{\circ}$ robot mengalami benturan dengan halangan, ini terjadi karena sensor ultrasonik kanan dan depan membaca jarak dekat, sensor kiri juga membaca jarak dekat. Hal ini berakibat pada putaran robot yang cenderung ke kanan dan dapat berakibat pada benturan terhadap halangan.

Dari 40 kali percobaan, robot tank berhasil menghindari halangan dalam 34 percobaan, dan gagal menghindari halangan dalam 6 percobaan. Sehingga dapat diambil nilai rata-rata keberhasilan dan kegagalan robot tank menghindari halangan :

$$
\begin{aligned}
& \text { Rata }- \text { rata keber hasilan }=\frac{34}{40} \times 100 \%=85 \% \\
& \text { Rata }- \text { rata kegagalan }=\frac{6}{40} \times 100 \%=15 \%
\end{aligned}
$$

\section{PENUTUP}

\section{$5.1 \quad$ Kesimpulan}

Berdasarkan perancangan, analisa dan pengujian yang telah dilakukan terhadap Robot Tank automatik pendeteksi halangan dengan kendali fuzzy logic ini didapatkan kesimpulan sebagai berikut :

1. Dari pengujian sensor ultrasonik, didapat nilai error pembacaan jarak $4,525 \%$ yang berpengaruh terhadap keluaran PWM masing-masing motor.

2. Penggunaan sensor HC-SR04 untuk mendeteksi halangan telah dapat bekerja dengan baik dengan nilai rata-rata keberhasilan robot tank menghindari halangan $85 \%$. Dan nilai rata-rata kegagalan $15 \%$. Kegagalan sering terjadi pada sudut $30^{\circ}$ dengan arah belokan ke kiri. Hal ini terjadi karena sempitnya sudut belokan dan juga karena pergerakan robot yang cenderung berbelok ke kanan.

3. Penggunaan roda belt tank memungkinkan robot tank untuk melewati jalan bergelombang dan tidak rata, maupun mendaki dan menurun.

\subsection{Saran}

Adapun saran sebagai masukan guna penelitian lebih lanjut dari tugas akhir ini adalah :

1. Dapat dilakukan perancangan kembali pengendali logika fuzzy, dengan basis aturan maupun fungsi keanggotaan (masukan maupun keluaran) yang berbeda untuk mendapatkan hasil yang lebih memuaskan.

2. Penambahan sensor ultrasonik akan menjadikan robot lebih sensitif dalam membaca adanya halangan. 
3. Penambahan encoder untuk menghitung perlambatan dan percepatan roda akan menjadikan robot lebih responsif terhadap perubahan sudut.

4. Robot tank ini bisa ditambahkan kamera, sehingga robot bisa dipantau dari jarak jauh.

\section{DAFTAR PUSTAKA}

[1] Anonymous. 2013. Mobile robot. http://en.wikipedia.org/wiki/Mobile robot\#Classification. Diakses tanggal 20 Juni 2013.

[2] Siregar, Iskandar Pahlevi. 2008. Perancangan Robot Penghindar Rintangan Menggunakan Mikrokontroler Scenix BS2SX28AC/DP. Bandung : Unikom.

[3] Budiharto, Widodo. 2010. Robot Tank dan Navigasi Cerdas. Jakarta : PT. Elex Media Komputindo.

[4] Tardi, Moh. Ibnu Malik Anis. 2009. Aneka Proyek Mikrokontroler PIC16F84/A. Jakarta : PT. Elex Media Komputindo.

[5] Anonymous. 2013. Arduino. http://arduino.cc/en/. Diakses tanggal 10 April 2013

[6] Anonymous. 2013. AVR Programmers. http://avrprogrammers.com/ devices/ATmega/atmega328. Diakses tanggal 10 April 2013.

[7] Djuandi, Feri. 2011. Pengenalan Arduino. www.tobuku.com/docs/ Arduino-Pengenalan. Diakses tanggal 11 April 2013.

[8] Suyadhi, Taufiq Dwi Septian. 2010. Buku Pintar Robotika. Yogyakarta: Andi Offset.

[9] Anonymous. 2013. Ultrasonic Range Sensor Module HC-SR04. http://www.famosastudio.com/ultrasonic-range-sensor-hc-sr04. Diakses tanggal 10 April 2013.

[10] Malvino, Albert Paul, Ph.D. 1985. Prinsip-Prinsip Elektronika I, Edisi Ketiga, Jilid 1. Jakarta : Erlangga.

[11] Anonymous. 2013. Arduino Motor Shield. http://www.dfrobot.com/wiki/

index.php?title=Arduino_Motor_Shield_(L298N)_(SKU:DRI0009). Diakses pada tanggal 11 April 2013.

[12] Syahrul. 2012 . Mikrokontroler AVR ATmega 8535. Bandung : Informatika Bandung.

[13] Mulyanto, Edy, dkk. 2011. Kecerdasan Buatan. Yogyakarta : Andi Offset.

1. [14] Guritno, Suryo, dkk. 2011. Theory and Application of IT Research Metodologi Penelitian Teknologi Informasi. Yogyakarta : Andi Offset.

[15] Hasibuan, Zainal A., PhD. . 2007. Metodologi Penelitian Pada Bidang Ilти Komputer dan Teknologi Informasi. Depok : Universitas Indonesia. 